\title{
РОЛЬ «ЗЕЛЕНОЙ ЭКОНОМИКИ» В УСТОЙЧИВОМ РАЗВИТИИ ЭКОЛОГО-ЭКОНОМИЧЕСКОЙ СИСТЕМЫ КАЗАХСТАНА
}

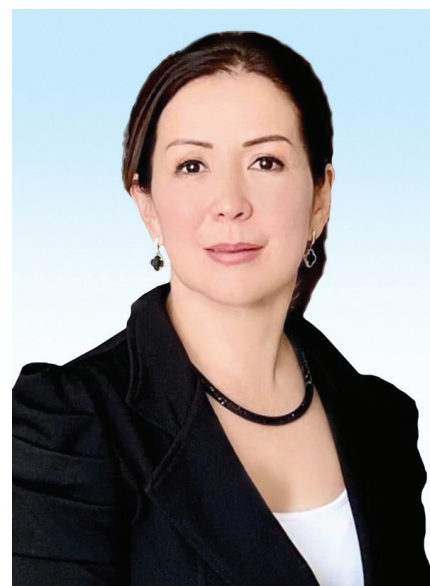

Г.Т. ШАКУЛИКОВА, доктор экономических наук, профессор, академик КазНАЕН, Председатель

Правления - ректор, https://orcid.org/0000-00023867-9747

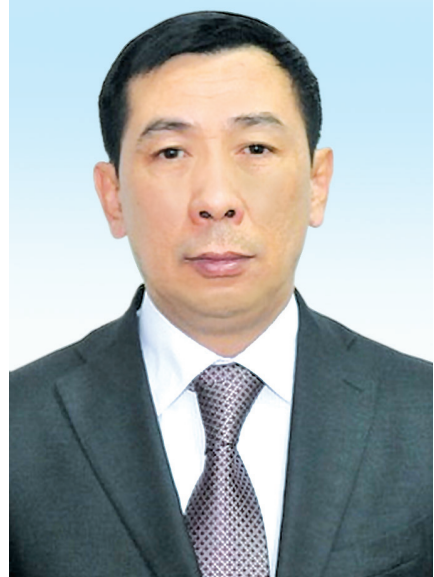

C.M. AXMETOB, доктор технических наук, профрессор, академик НИА РК, индустриальный руководитель, https://orcid.org/0000-00021983-457X

НАО «АТЫРАУСКИЙ УНИВЕРСИТЕТ НЕФТИ И ГАЗА ИМ. САФИ УТЕБАЕВА», Республика Казахстан, 060000, г. Атырау, ул. Баймуханова, 45 А

На основе обзора государственных программ, законодательных актов и положений, принятых в республике, и регламентирующих реализаций основные принципы и нормы внедрения концепции «зеленой экономики», а также анализа состояния современных исследований в данной области обоснована ее роль в устойчивом развитии эколого-экономических систем Казахстана. Предложена блок-схема последовательности, которая позволила проанализировать опыт внедрения, а также существующие научные разработки в области возобновляемых и альтернативных источников энергии в дальнем зарубежье и соседних государствах. Это позволило научно обосновать целесообразность и эфрфективность дальнейшего развития в Казахстане ветровой и солнечной энергетики, а также внедрение новых видов альтернативных источников энергии на индустриальной основе. При решении поставленной задачи использовался метод сопоставительного анализа имеющихся данных. Большое внимание уделено подробному анализу проектов Программ развития ОНН (ПРООН), реализованных в стране в 2004-2014 г2., как основе начала системных процессов развития в Казахстане «зеленой экономики». Предложены новые подходы в определении мотивации использования в энергетическом секторе Казахстана альтернативных и возобновляемых источников энергии, определены необходимые условия их реализации.

КЛЮЧЕВЫЕ СЛОВА: «зеленая экономика», возобновляемые и альтернативные источники энергии, проекты ООН, устойчивое развитие эколого-экономических систем. 


\section{ҚАЗАҚСТАННЫҢ ЭКОЛОГИЯЛЫҚ-ЭКОНОМИКАЛЫҚ ЖҮЙЕЛЕРІНІҢ ТҰРАҚТЫ ДАМУЫНДАҒЫ «ЖАСЫЛ ЭКОНОМИКАНЫҢ» РӨЛІ}

Г.Т. ШАКУЛИкОВА, экономика ғылымдарының докторы, профессор, ҚазҰЖҒА академигі, https:// orcid.org/0000-0002-3867-9747

С.М. АХМЕТОВ, техника ғылымдарының докторы, профессор, ҚР ҰИА академигі, https://orcid. org/0000-0002-1983-457X

«САФИ ӨТЕБАЕВ АТЫНДАҒЫ АТЫРАУ МҰНАЙ ЖӘНЕ ГАЗ УНИВЕРСИТЕТІ» КЕАҚ, Қазақстан Республикасы, 060000, Атырау қ., Баймұханов к., 45 А

Республикада қабылданған және «жасыл экономиканың» негізгі тұжырымдамалары мен нормаларын іске асыруды регламенттейтін мемлекеттік бағдарламаларға, заңнамалық актілер мен ережелерге шолу жүргізу, сондай-ақ осы саладағы қазіргі заманғы зерттеулердің жай-күйін талдау негізінде олардың Қазақстанның экологиялық-экономикалық жүйелерінің орнықты дамуындағы рөлі негізделген. Алыс шет елдер мен көршілес мемлекеттердегі енгізілу тәжірибесі, сондай-ақ олардағы жаңартылатын және баламалы энергия көздері саласындағы қолданыста бар ғылыми зерттеулер нәтижелерін талдауға мүмкіндік берген жүйеліліктің блок-схемасы ұсынылды. Бұның өзі Қазақстанда жел және күн энергетикасын одан әрі дамытудың орындылығы мен тиімділігін ғылыми негіздеуге, сондай-ақ баламалы энергия көздерінің жаңа түрлерін елімізде индустриялық негізде енгізудің мүмкін екендігін тұжырымдады. Қойылған мәселелерді шешу үшін қолда бар деректерді салыстырмалы талдау әдісі қолданылды. Қазақстанда «жасыл экономиканы» дамытудағы жүйелі процестердің басталуының негізі ретіндегі елімізде 2004-2014 жылдары іске асырылған БҰҰ даму Бағдарламалары (БҰҰДБ) жобаларының егжей-тегжейлі талдауына көп көңіл бөлінді. Қазақстанның энергетикалық секторында баламалы және жаңартылатын энергия көздерін пайдаланудың уәждемесін айқындауда жаңа тәсілдер ұсынылды, оларды іске асырудың қажетті шарттары айқындалды.

ТҮЙІн СөзДЕР: «жасыл экономика», жаңартылатын және баламалы энергия көздері, БҰҰ жобалары, экологиялық-экономикалық жүйелердің тұрақты дамуы.

\section{THE ROLE OF THE "GREEN ECONOMY" IN THE SUSTAINABLE DEVELOPMENT OF ECOLOGICAL AND ECONOMIC SYSTEMS OF KAZAKHSTAN}

G.T. SHAKULIKOVA, doctor of Economic Sciences, Professor, academician of the Kazakh National Academy of Natural Sciences, https://orcid.org/0000-0002-3867-9747

S.M. AKHMETOV, doctor of technical sciences, professor, academician of the National Engineering Academy of the Republic of Kazakhstan, https://orcid.org/0000-0002-1983-457X

\section{S. UTEBAYEV ATYRAU UNIVERSITY OF OIL AND GAS} 45 A, Baimukhanov str., Atyrau, 060000, Republic of Kazakhstan

Based on the review of state programs, legislative acts and regulations adopted in the republic and statutory implementations, the basic principles and norms of the introduction of the concept of "green economy", as well as the analysis of the state of modern research in this area, its role in the sustainable development of ecological and economic systems of Kazakhstan are substantiated. A flowchart of the sequence is proposed, which made it possible to analyze the experience of implementation, as well as existing scientific developments in the field of renewable and alternative energy sources in the far abroad and neighboring countries. This made it possible 
to scientifically ground the feasibility and effectiveness of further development of wind and solar energy in Kazakhstan, as well as the introduction of new types of alternative energy sources on an industrial basis. When solving the task, the method of comparative analysis of available data is used. Much attention is paid to the detailed analysis of the projects of the Development Programs of the UN (UNDP) implemented in the country in 2004-2014, as the basis for the beginning of the systemic processes of development of the "green economy" in Kazakhstan. New approaches are proposed in determining the motivation for the use of alternative and renewable energy sources in the energy sector of Kazakhstan, the necessary conditions for their implementation are determined.

KEY WORDS: "green economy", renewable and alternative energy sources, UN projects, sustainable development of ecological and economic systems.

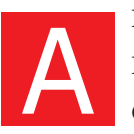

нализ зарубежных источников научной информации показал растущую роль и важность рационального использования природных энергоресурсов как одного из ключевых элементов эколого-экономических систем в устойчивом росте экономики [1-3]. В глобализации данного процесса особое место занимают такие организации, как Европейский Союз (ЕС), а также другие мировые институты общественного движения [1]. Одна из ключевых задач ЕС - это переход к полной декарбонизации экономики к 2050 году. В рамках этой стратегической концепции цель развития возобновляемой энергетики играет ключевую роль.

Необходимо отметить, что декарбонизация в условиях продолжающегося глобального потепления и увеличения выбросов парниковых газов требует ускорения глобальных темпов повышения энергоэффективности и устойчивого использования энергии. В этом сложном процессе важную роль также играет применение поведенческого анализа в развивающихся странах, в том числе и для Казахстана, где в будущем спрос на энергию значительно возрастет, а потенциал для повышения энергоэффективности огромен [2]. Исследованиями доказано, что ВИЭ является вопросом как экономическим, так и политическим, что нужно учитывать при формировании стратегии развития регионов [3].

Принятая в 2012 г. Стратегия «Казахстан-2050»: новый политический курс состоявшегося государства» (далее Стратегия-2050) определила перед государством четкие задачи на построение устойчивой и эффективной модели экономики, основанной на переходе страны на «зеленый» путь развития [4]. Это было началом практической реализации «зеленой экономики», которая со временем стала одним из действенных инструментов регулирования устойчивостью развития эколого-экономической системы страны, о чем свидетельствует государственный план мероприятий «Зеленый Казахстан», утвержденный Правительством РК до 2030 года. Это является одним из важных событий в деле реализации Концепции по переходу республики к «зеленой экономике» [5-9]. Ее суть заключается в организации экономики государства с высоким уровнем качества жизни населения, бережным и рациональным использованием природных ресурсов в интересах нынешнего и будущих поколений в соответствии с принятыми в РК международными экологическими обязательствами (принципы Рио-де-Жанейро, Йоханнесбургский план, Декларация Тысячелетия и т.д.) [8, 9]. При этом ожидается, что, по прогнозным расчетам, к 2050 году преобразования в рамках «зеленой экономики» позволят стране дополнительно 
увеличить ВВП на 3\%, создать более 500 тысяч новых рабочих мест, сформировать новые отрасли промышленности и сферы услуг, обеспечить повсеместно высокие стандарты качества жизни для населения. Кроме того, ожидается, что объем инвестиций, необходимый для перехода на «зеленую экономику», составит порядка $1 \%$ ВВП ежегодно, что эквивалентно 3-4 млрд долларов США в год.

В общих подходах по переходу к «зеленой экономике», которая охватывает все стороны ее эффективной реализации в жизнь важное место уделено сектору развития электроэнергетики как ключевому фактору обеспечения республики необходимой мощностью [10]. В документе сказано, что растущий в перспективе спрос на электроэнергию в Казахстане потребует значительного строительства новых мощностей: 11-12 ГВт к 2030 году и 32-36 ГВт к 2050 году. Причем, указанные цифры были прогнозированы без учета установленных мощностей ВИЭ, а также альтернативных и нетрадиционных запасов энергоносителей, т.к. тогда это направление считалось нестабильным. Однако мировой опыт развития энергосистем за последние 8 лет показывает чрезвычайную актуальность применения ВИЭ в качестве дополнительных, а в некоторых отраслях - как основных источников энергии. Такая перспектива была предусмотрена именно в Стратегии-2050.

В качестве основных факторов, от которых в существенной мере зависит развитие энергетического сектора страны были выделены следующие возможные сценарии:

1) Базовый сценарий - спрос на электроэнергию в базовом сценарии, газификация Акмолинской и Карагандинской области, сохранение текущих низких цен на газ, 30\% доля альтернативных источников в производстве электроэнергии в 2050 г.;

2) «Зеленый» сценарий - дорогой газ: спрос на электроэнергию при выполнении целей «зеленой экономики», газификация Акмолинской и Карагандинской области, высокие цены на газ, 50\% доля альтернативных источников в производстве электроэнергии в 2050 г;;

3) «Зеленый» сценарий - дешевый газ: спрос на электроэнергию при выполнении целей «зеленой экономики», газификация Акмолинской, Карагандинской, Павлодарской и восточных областей, низкие цены на газ, 50\% доля альтернативных источников в производстве электроэнергии в 2050 г.

Анализ вышеуказанных вариантов моделирования процесса свидетельствует о высокой роли «зеленой экономики». Это подтверждает также и следующие некоторые прогнозируемые показатели [4]:

- ожидается, что средняя стоимость производства электроэнергии возрастет примерно вдвое к 2030 г. и втрое к 2050 г. по сравнению с уровнем 2012 г., достигнув 7-9 тенге/кВтч в 2030 году и 10-14 тенге/кВтч в 2050 году;

- общие инвестиции, в том числе меры по повышению энергоэффективности, модернизацию, пылегазоочистное оборудование, строительство новых мощностей и создание инфраструктуры, составят 40-55 млрд. долларов США к 2030 г. и 90-130 млрд. долларов США к 2050 году в зависимости от сценария и эволюции технологий производства электроэнергии;

- объем электроэнергии, производимой угольными станциями, останется примерно на сегодняшнем уровне до 2030 года во всех сценариях: 60-75 ТВт-ч в 2030 году 
по сравнению с 70 ТВТ-ч в 2012 г. Объем годового потребления угля энергетическим сектором незначительно сократится до 40-50 млн. тонн в 2030 г. по сравнению с уровнем 2012 г., т.е. более 50 млн. тонн в основном из-за повышения эффективности модернизированных и новых угольных электростанций;

- доля атомной энергетики во всех сценариях составит примерно 7-8\% от общего объема производимой электроэнергии как в 2030 г., так и в 2050 г.;

- несмотря на двукратный рост производства электроэнергии, объем выбросов $\mathrm{CO} 2$ незначительно сократится с 90 миллионов тонн в год до 75-85 миллионов тонн в год к 2030 г., в основном из-за развития атомной, альтернативной энергетики и увеличения доли газа в структуре производства электроэнергии.

При этом, учитывая перспективу внедрения ВИЭ в энергосистеме страны, была поставлена задача - начать строительство ветряных и солнечных электростанций (ВЭС и СЭС соответственно) с достижением их доли в общем объеме производства энергии по следующим показателям:

- 3\% доли ВЭС и СЭС в общем объеме производства электроэнергии к 2020 г.;

- 10\% доли ВЭС и СЭС в общем объеме производства электроэнергии к 2030 г;; переход к полномасштабному внедрению ВИЭ после достижения ими приемлемого уровня конкурентоспособности по сравнению с традиционными источниками, что ожидается в период между 2020 и 2030 гг;

- 50\% доли ВЭС и СЭС в общем объеме производства электроэнергии к 2050 г.

Как видно из вышеприведенных примеров, учитывая имеющийся потенциал Казахстана по ветровым, солнечным и другим видам энергоресурсов в стране придается большое значение применению ВИЭ в общем объеме производства электроэнергии, что определяет актуальность данной проблемы.

Проанализируем современное состояние развития ВИЭ, а также альтернативных и нетрадиционных технологий совершенствования энергосистемы в зарубежных странах, в постсоветских государствах, в т.ч. и в РК, где методику изучения предлагаем реализовать по следующей схеме последовательных взаимосвязанных подсистем (рисунок 1).

В 2009 по заказу Кластерного бюро ЮНЕСКО в г. Алматы группой национальных экспертов был подготовлен обзор для освещения ситуации по текущему состоянию дел и перспективам применения ВИЭ в Республике Казахстан, Кыргызской Республике, Республике Таджикистан и Республике Узбекистан на основе анкетирования заинтересованных сторон, изучения документов международных проектов и других открытых литературных источников.

В работе [11] было представлено положение дел по использованию ВИЯ в странах Центральной Азии (ЦА). Были исследованы не столько технический потенциал стран ЦА в области развития ВИЭ, сколько прояснена позиция заинтересованных сторон в их развитии и готовность их к проведению приемлемой эколого-экономической политики. Признавая тот факт, что квалифицированные кадры являются важным элементом в деле внедрения и передачи новых технологий со стороны ЮНЕСКО была поставлена задача оценить потребности стран в получении новых знаний, необходимых для развития использования ВИЭ в регионах и таким обра- 


\section{АКТУАЛЬНО}

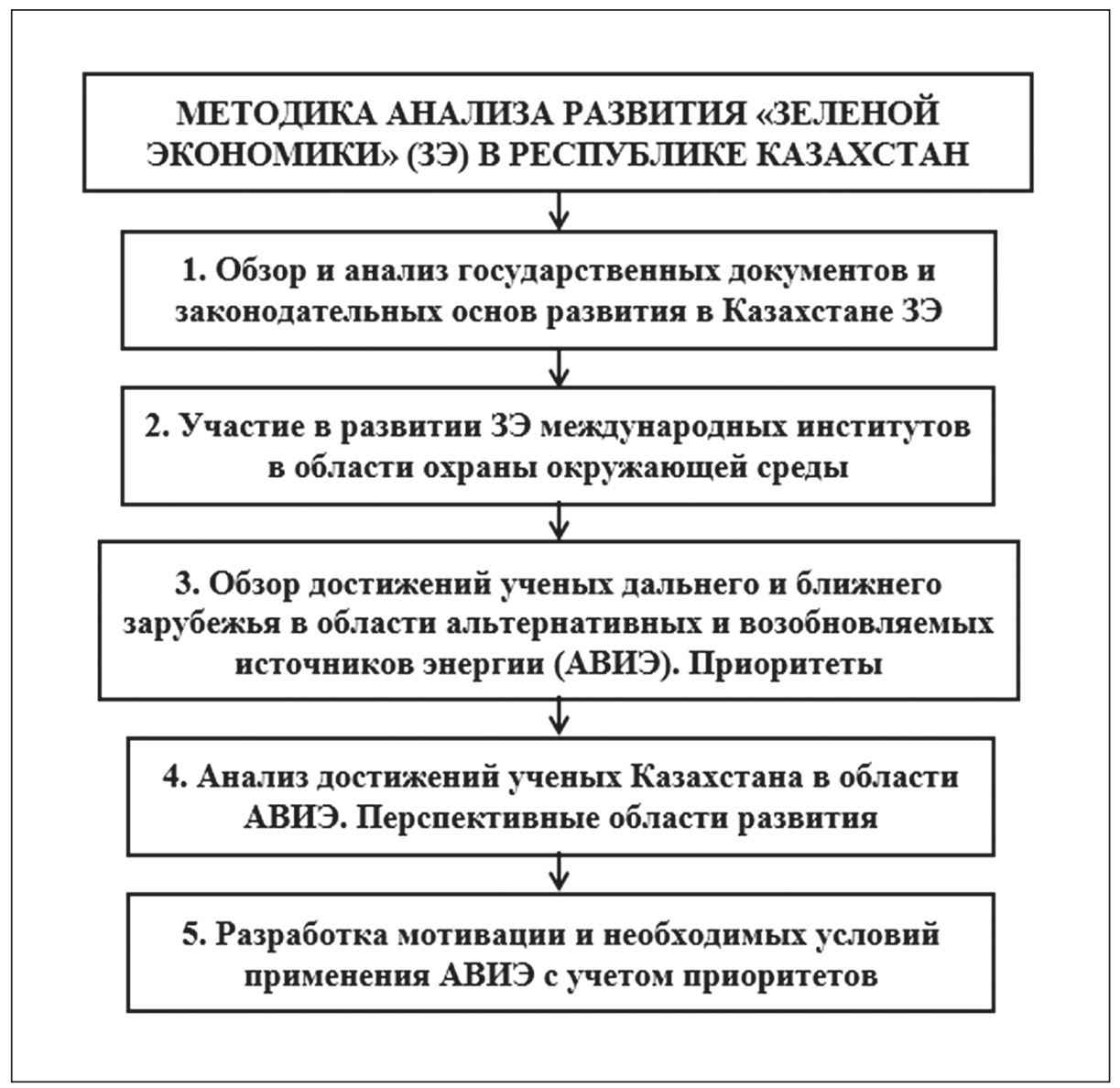

Рисунок 1 - К методике анализа состояния применения ВИЭ в зарубежных государствах и Республике Казахстан

(блок-схема последовательности анализа предложена авторами статьи)

зом прояснить, какие тренинги, обучающие программы особо необходимы для их продвижения в регионах.

Развитие ВИЭ в стране обуславливается наличием значительного потенциала данных источников, что делает этот сектор перспективным и инвестиционно-привлекательным направлением развития энергетической сферы в республике. По мнению экспертов, для территории Казахстана наиболее перспективны следующие виды ВИЭ [12]:

- ветроэнергетика;

- малые гидроэлектростанции;

- солнечные установки для производства тепловой и электрической энергии;

- использование энергии подземных вод и т.д.

В соответствии с государственной Программой по форсированному индустриально-инновационному развитию Республики Казахстан перспективными районами для развития ветроэнергетики являются Алматинская, Акмолинская, Жамбылская, 
Западно-Казахстанская, Атырауская и Мангистауская области и другие регионы. Однако, несмотря на наличие разведанного запаса ветроэнергоресурсов, в РК не все регионы задействованы в применении возможностей ВИЭ. По данным Казахстанской Ассоциации солнечной энергетики при Министерстве энергетики РК, к 2020 г. суммарная мощность всех видов ВИЭ, применяемых в стране, должна была достичь до 1655 МВт от построенных 108 объектов (рисунок 2).

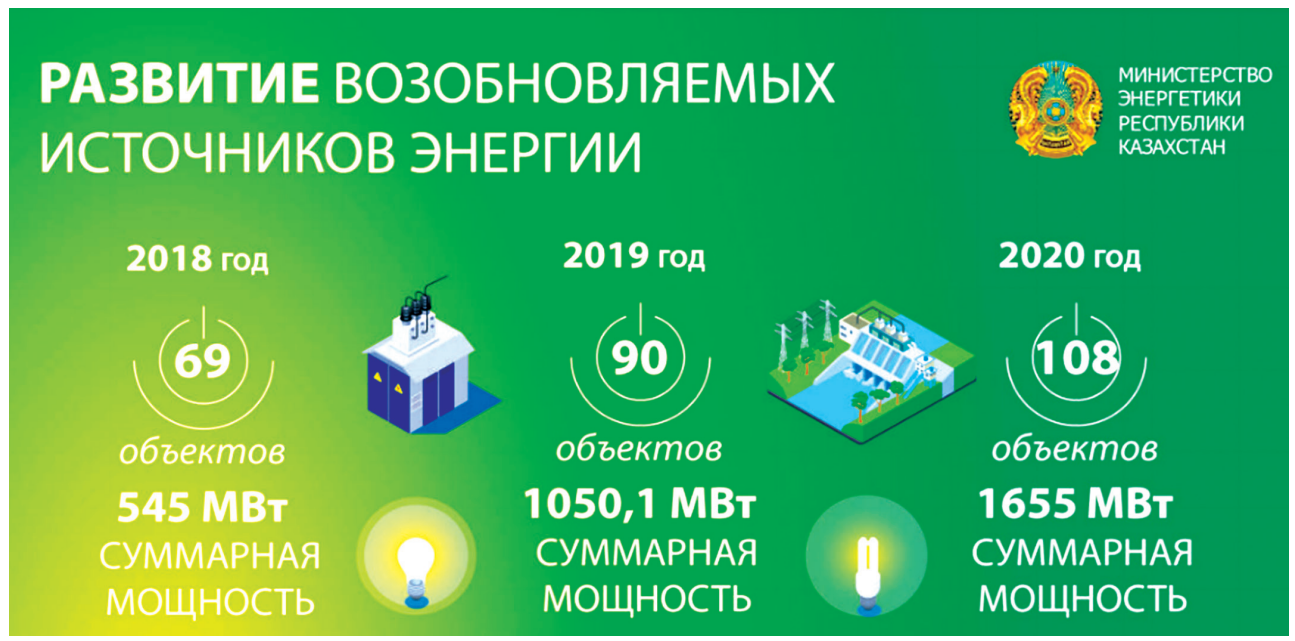

Рисунок 2 - Суммарная мощность, вырабатываемая за счет внедрения ВИЭ за 2018-2020 гг. (данные получены из ресурсов Казахстанской Ассоциации солнечной энергетики при Министерстве энергетики РК)

Следует отметить, что процесс рассматривания ВИЭ, а также альтернативных и нетрадиционных технологий как перспективно возможных источников производства энергии в Казахстане был начат гораздо раньше, начиная с 1996 г. Важная роль в данном процессе отведена институтам всемирной Организации Объединенных Нации $(\mathrm{OOH})$. Об этом свидетельствует активное участие программ $\mathrm{OOH}$ в развитии ВИЭ в Средней Азии, в том числе и в Казахстане.

Проанализируем основные мероприятия, проведенные с участием институтов $\mathrm{OOH} \mathrm{в} \mathrm{целях} \mathrm{реализации} \mathrm{в} \mathrm{республике} \mathrm{программ} \mathrm{внедрения} \mathrm{ВИЭ.}$

За годы независимости в республике были приняты ряд мер и государственных программ, в которых отражены законодательные основы использования возобновляемых энергетических ресурсов $[11,13]$.

Первым законодательным актом в данном направлении было Постановление Правительства РК от 19 апреля 1996 года № 474 «О мерах по реализации энергосберегающей политики в Республике Казахстан», где обозначено, что одним из первоочередных мер по реализации Программы энергосбережения является (п.3) - разработка мер по поддержке хозяйствующих субъектов, осуществляющих мероприятия по энергосбережению и внедрению нетрадиционных источников энергии с образованием целевого фонда энергосбережения и внедрения нетрадиционных источников энергии. Во исполнение разработанных мер Министерством энергетики и природных ресурсов РК в свое время были изданы приказы: №6 от 18.03.97 г. 
«О вовлечении в энергобаланс возобновляемых энергоресурсов» и №14 от 12.01 .00 г. «О создании рабочей группы по развитию отечественной ветроэнергетики» [10].

В следующем государственном документе (Закон «Об энергосбережении» от 25.12.97 г. №210-I) дано определение ВИЭ как источникам постоянно существующих или периодически возникающих в окружающей среде потоков Солнца, ветра, тепла Земли, биомассы и рек [13]. На основании данного Закона Министерством энергетики, индустрии и торговли РК был издан приказ от 21.10.98г. «Об организации реализации Закона Республики Казахстан «Об энергосбережении» для освоения возобновляемых источников энергии и практической реализации данного Закона. Была создана ведомственная комиссия по реализации энергосберегающей политики, где функции вовлечения в энергобаланс Республики Казахстан возобновляемых ресурсов были возложены на институт «Казсельэнергопроект» [13].

Следующим нормативно-правовым актом является Постановление Правительства РК от 09.04.99г. № 384 «О программе развития электроэнергетики до 2030 года». Закон был направлен на решение экологической проблемы Казахстана и тесно связано с использованием возобновляемых энергетических ресурсов, т.к. их потенциал (гидроэнергия, ветровая и солнечная энергия и др.) весьма значителен [13].

В целях выполнения международных обязательств, принятых Казахстаном по Рамочной Конвенции ООН об изменении климата, Правительством РК 25 августа 2003 года было издано Постановление за №857 «О развитии ветроэнергетики». Согласно данному Постановлению было одобрено проектное предложение реализации в стране Программы развития ООН (ПРООН) Глобального экологического фонда (ГЭФ) «Ускорение развития ветроэнергетики в Казахстане», а также предложение по строительству пилотной ВЭС мощностью 5 МВт в районе Джунгарских ворот (Алматинская область) при участии и финансовой поддержке ПРООН/ГЭФ. Министерству энергетики и минеральных ресурсов РК как уполномоченному органу было поручено рассмотреть и принять решение о реализации проекта, решить вопрос подключения пилотной ВЭС к действующим электрическим сетям и привлечения внебюджетных средств в сумме 24 млн тенге как вклад Казахстана в разработку Программы развития ветроэнергетики.

Можно сказать, что именно с момента реализации проектов ООН в период с 2004 г. по 2014 г. были достигнуты значительные результаты по применению ВИЭ для усиления энергетического потенциала Казахстана.

В работах зарубежных исследователей [14-16] получены результаты численного моделирования и оптимизации пар ветряных турбин с вертикальной осью, новые подходы к проектированию их несущих элементов, а именно металлических конструкции матч. Это позволило авторам предложить различные варианты конструкции ВЭУ, которые эффективно срабатывают при любом направлении скорости ветра.

В работе [17] обсуждаются вопросы экономических последствий продвижения в Германии проектов по ВИЭ. Как известно, за последнее десятилетие Германия расширила производство энергии из возобновляемых источников за счет крупных субсидий. Однако учитывая, что данный процесс является очень дорогостоящим из-за установленных в стране высоких цен на электроэнергию, которые вызывают опасения, авторами допускается возможность внедрения ВИЭ преимущественно в 
бедных домохозяйствах. Математико-статистическое моделирование и регрессионный анализ вычисленных данных позволили авторам сделать вывод о том, что реализации ВИЭ могут быть смягчены изысканием альтернативных механизмов финансирования субсидий.

В работе [18] прогнозируется перспективы комплексного применения различных видов ВИЭ путем их гибридизации, что является одним из актуальных направлений в данной области. Работа гибридных источников энергии основана на взаимодополняемости возобновляемых источников, например, ветро-солнечной, гидро-солнечной, гидро-солнечно-ветровой и т.п.

Идея гибридизации нашла широкую поддержку за счет возможности достичь синергетического эффекта в конкретном случае, при научно обоснованном рациональном подборе взаимодополняемых источников. Так, в работе [19] авторы смоделировали и оптимизировали параметры возобновляемой гибридной энергосистемы, состоящей из солнечных фотоэлектрических элементов, ветряных турбин, преобразователей и аккумуляторной системы накопления энергии. Созданная им имитационная модель позволяет проанализировать размер, оптимизировать затраты и таким образом построить стратегию управления гибридной энергетической системой. В работе определена оптимальная архитектура системы производства электроэнергии из возобновляемых источников для одного из крупнейших мегаполисов Канады, города столичного значения Виктория.

B работе [20] анализированы снимки спутниковых данных MERRA-2, чтобы сравнить и применить их при моделировании на разных высотах воздушного потока в различных регионах Боливии. Результаты были получены при скорости ветра на разных участках, который варьировался от 0,90 до 1,09, и периодами высоких скоростей ветра, которые имеют место в данной зоне. Из данного примера можно проследить перспективы применения космических технологий и дистанционного зондирования Земли (ДЗ3) в управлении процессом освоения технологии применения ВИЭ.

Некоторые результаты зарубежных исследователей представляют собой работы концептуально-обзорного характера и посвящены они политическим вопросам внедрения ВИЭ, а именно к критике взаимосвязи между концентрированной или распределенной возобновляемой энергией и политической властью. Исследователи рассматривают процесс перехода к ВИЭ в качестве политического противостояния, где усилия по переходу от ископаемого топлива и декарбонизации общества не будут эффективными без дестабилизации доминирующих систем энергетической власти [21]. Таким образом, авторами сделана попытка по поиску способов реорганизации распределенных потоков энергии в агрегированные и концентрированные запасы энергии и другие формы политической власти.

Как известно, одним из немаловажных факторов является правильный выбор места для установки технических средств являющимися объектами ВИЭ, т.к. от этого зависит, насколько продолжительно и эффективно можно будет использовать природные источники энергии. Причем, это относится не только к ветроустановкам, но и другим видам системы ВИЭ, например, солнечным установкам. В данном направлении актуален вопрос оптимального использования солнечной энергии в 
холмистой или горной местности, где знание количества и продолжительности солнечной радиации в пределах данной топографической местности считается важным. Это связано с тем, что, как правило, данные о солнечной радиации недоступны для большинства горных территорий из-за их пересеченной местности. Именно в целях обеспечения данными о солнечной радиации горные районы, где будут установлены СЭС, была посвящена работа [22], где применяется один из альтернативных методов, такой как алгоритм Hemispherical Viewshed, в котором пространственные и временные изменения радиации вычисляются с учетом высоты, уклона и топологии местности. Этот алгоритм использовался для оценки и моделирования солнечной радиации в горе Парау в Керманшахе.

В последнее время стал применяться микросайтинг для эффективного использования наземных и прибрежных ВЭС, которые могут быть установлены в автономных зонах, представляющих собой острова. К примеру, в районе Адалар Стамбула (Принцевы острова) была анализирована выработка энергии, сравнены значения скорости ветра между 2017 и 2019 гг. на основании полученных данных от метеорологической станции Бююкада и станции буй Адалара соответственно. Это позволило определить авторам данной разработки определить реальную потребность острова в электроэнергии, которая может быть удовлетворена 93,3\% за счет морских ВЭС, и что, производство электроэнергии из островных ВИЭ обеспечит инвестору экономическую выгоду [23].

Исследования, реализуемые в мировом научном пространстве, как правило, оказывают соответствующие влияния на формирование единой концепций в реализации тех или иных идеи, что несомненно отражаются также и в других государствах.

В соседних государствах постсоветского пространства, в частности в России, Белоруссии и Кыргызстане проводится целенаправленная работа по внедрению ВИЭ, а также альтернативных и нетрадиционных технологий производства энергии, которые регулируются государственными и иными институтами, посредством законов и подзаконных актов, правилами и положений. Они являются информационно-аналитической основой для ускоренного перехода Казахстана в «зеленую энергетику».

В работах $[24,25]$ исследованы особенности «зеленой» экономики в современных реалиях, экологических проблем устойчивого развития. Сделана попытка оценки истории, состояния и перспектив развития мировой и отечественной ветроэнергетики. Показаны этапы развития, роль отечественной и отраслевой науки, возможности отечественной производственной базы и пути её совершенствования [25]. Применен количественный метод анализа в сочетании с качественными методами систематизации, интерпретации, сравнения научной информации, практических материалов международных организаций. Это позволило исследователям прийти к выводу, что для решения экологических проблем устойчивого развития приоритетными должны быть: усиление роли государства в развитии «зеленой» экономики» для совершенствования правовых механизмов регулирования экономического развития страны в данном контексте.

Источники научных информации свидетельствуют о проводимых в России исследовательских работах в области биогазовой технологии. Так, в работе [26] рассмотрена альтернативная замена нефтяного топлива на газ, получаемый из быто- 
вых и промышленных отходов, где переработка отходов городов и промышленных предприятий позволит решить также и экологические проблемы.

В последнее время часто стали говорить о геотермальных технологиях как одном из перспективных направлений альтернативной энергетики. В работах $[27,28]$ подробно раскрыты вопросы внедрения в России энергии ветра и Солнца, геотермальной энергии, а также энергии малых водных потоков, приливных электростанций и волновых электроустановок. Даны сведения об особенностях геотермальных месторождений и физико-химических свойствах геотермального теплоносителя. Рассмотрены особенности и преимущества конструкции образцов российского геотермального оборудования, включая сепараторы гравитационного принципа действия, паровые турбины с развитой системой внутриканальной сепарации влаги из проточной части, системы охлаждения и закачки отработавшего геотермального теплоносителя [28].

В процессе применения ВИЭ, особенно ВЭС, часто возникает необходимость проведения оценки их влияния на основные параметры режима работы электроэнергетических систем (ЭЭС). Для этого целесообразно использовать методы статистической обработки больших баз данных, методы оптимизации, а также численные методы [29]. В данной работе авторами разработан метод, позволяющий выбрать наиболее рациональные узлы ЭЭС при помощи выявленных критериев на этапе проектирования при определении мест установки ветровых электростанций. Таким образом, проведенные исследования определяют простой и практически применимый подход к определению наиболее оптимальных площадок для размещения ветровых электростанций.

Немаловажен в «зеленой экономике» применение когенерации, который позволяет интерпретировать различные виды источников энергии для получения тепловой энергии.

В работе автора представлен анализ последствий для теплоснабжения при использовании возобновляемых источников энергии с целью замещения электроэнергии дизельных генераторов в изолированных системах электроснабжения с когенерацией. Предложен расчет для учета расхода угля на котельной с учётом загрузки когенерации дизельной станций [30].

Обзор научно-технической информации свидетельствует об активизации в России разработок по внедрению гибридной технологии ВИЭ [31-33]. Так, если для создании гибридной электростанции, работающей от солнечных коллекторов и газотурбинной установки, был рассчитан рейтинг и произведено сравнение отдельных провинций государства в целях определения наилучшего региона и размещения подобных гибридных станций с комбинированным циклом [31], то в работе [32] рассмотрена возможность использования стратегии управления распределением нагрузки для гибридной системы, состоящей из фотоэлектрических панелей, дизельного генератора и аккумуляторных батарей, работающей по заданному графику нагрузки с известными циклами зарядки/разрядки батарей. В работе [33] изучены особенности работы генерирующих установок, функционирующих на основе ВИЭ, в составе гибридного энергокомплекса и определены требования, предъявляемые генерирующим установкам и накопительным системам по объемам запасаемой 
энергии, а также режимам приема и отдачи мощности на продолжительных, средних и коротких интервалах времени.

В настоящее время как в России, так и в других некоторых государствах постсоветского государства активно стали заниматься проблемой освоения энергии водорода, так называемой водородной энергетикой. Об этом свидетельствуют результаты, полученные в специализированных научных организациях, а также исследования отдельных ученых. В данной технологии, кроме процесса получения и хранения самого водорода, немаловажный интерес представляет разработка технических средств получения энергии от него $[34,35]$. Это связано с тем, что для получения энергии от водорода последний должен быть использован в качестве топлива в двигателях внутреннего сгорания (ДВС). Данная ситуация требует разработки нового типа ДВС, которые имеют особенности в отличие от обычных их разновидностей. В этом контексте были проанализированы основные возможности для производства, транспортировки, использования водорода на предприятиях Татарстана, который может стать конкурентоспособным регионом России по производству и дистрибьюции «зеленого» водорода. Основные проблемы в этом случае заключаются в получении чистого водорода, промышленное производство грузового транспорта на топливных элементах, производство электролизеров мегаваттного класса, утилизация водородсодержащих нефтяных газов на ТЭС в газовых турбинах или комбинированных циклах с топливными элементами и т.д. [34]. Также показано, что в этом отношении Россия в целом имеет ряд важных преимуществ в развитии водородной энергетики, которые могут привести к выходу на международные рынки технологий и энергоносителей [35].

Огромный научно-практический интерес представляют так называемые мини тепло- и гидроэлектростанции, основанные на использовании монотоплив и других видов альтернативных топлив, а также в применении природной энергии воды. Это в свою очередь создает необходимость разработки специальных устройств и технических средств, позволяющих получить теплоэнергию при сжигании нетрадиционных топлив для паротурбин, а также генераторов гидротурбин и ВЭС, способных вырабатывать электроэнергии при малых оборотах [36-39]. Обоснование и описание перспектив использования многотопливных микротепловых электростанций на основе двигателя Стирлинга для сельских районов. Основой микротепловой электростанции является двигатель с внешним подводом теплоты, работающий по термодинамическому циклу Стирлинга [36]. А в работе [37] для выявления эффектов внедрения технологий децентрализованной генерации использован метод анализа практических кейсов, проведенного на базе округов, менее всего электрифицированных и являющихся стратегическими пунктами при транспортировке энергии в соседние страны. В работе [38] предложено компактное подводное устройство для производства энергии, вырабатываемой подводными течениями и приливно-отливными явлениями на арктическом побережье для небольших поселков, которые будут созданы для слежения судов, идущих по Севморпути, и оказания оперативной помощи при необходимости. В работе [39] предложены варианты эффективных ветряных агрегатов, турбины которых способны вырабатывать электроэнергии при 


\section{АКТУАЛЬНО}

малых оборотах, а также пути их использования в приводах устройств для добычи нефти в качестве дополнительных источников мощностей.

Что касается состояния исследований, реализованных в Казахстане, то в отношении их приоритетных направлений, преобладающих среди множества частных разработок, ситуация выглядит несколько иначе.

Ниже приведем небольшой анализ некоторых работ казахстанских исследователей, которые посвящены к внедрению в республике ВИЭ, а также альтернативных и нетрадиционных технологий.

В целях устранения ожидаемых барьеров, препятствующих интенсивному и планомерному внедрению ВИЭ в Казахстане, ПРООН/ГЭФ и Министерство энергетики и минеральных ресурсов РК (ныне МЭ РК) в 2006 г. начали реализацию проекта «Казахстан - инициатива развития рынка ветроэнергетики» с бюджетом 7,274 миллиона USD. Глобальный Экологический Фонд (ГЭФ) внес вклад в размере 2,55 миллиона USD [40]. В соответствии с руководящими документами ПРООН и ГЭФ была проведена среднесрочная оценка, результаты которой представлены в данном материале отчета. Сформированная с этой целью группа провела среднесрочную оценку на месте, в Казахстане, в первой половине сентября 2007 г.

За данный период ПРООН оказал содействие Правительству РК в разработке и совершенствовании нормативно-правовой базы и государственного регулирования процесса внедрения в стране ВИЭ. В рамках технической помощи проведен анализ ветрового потенциала в 15 регионах Казахстана, разработаны общая карта по ВИЭ, а также карты годовой солнечной активности и Ветровой атлас (BA) Казахстана (puсунки 3, 4 и 5), которые позволяют принять правильные решения при определении приоритетного направления ВИЭ для каждого региона [41, 42, 43].

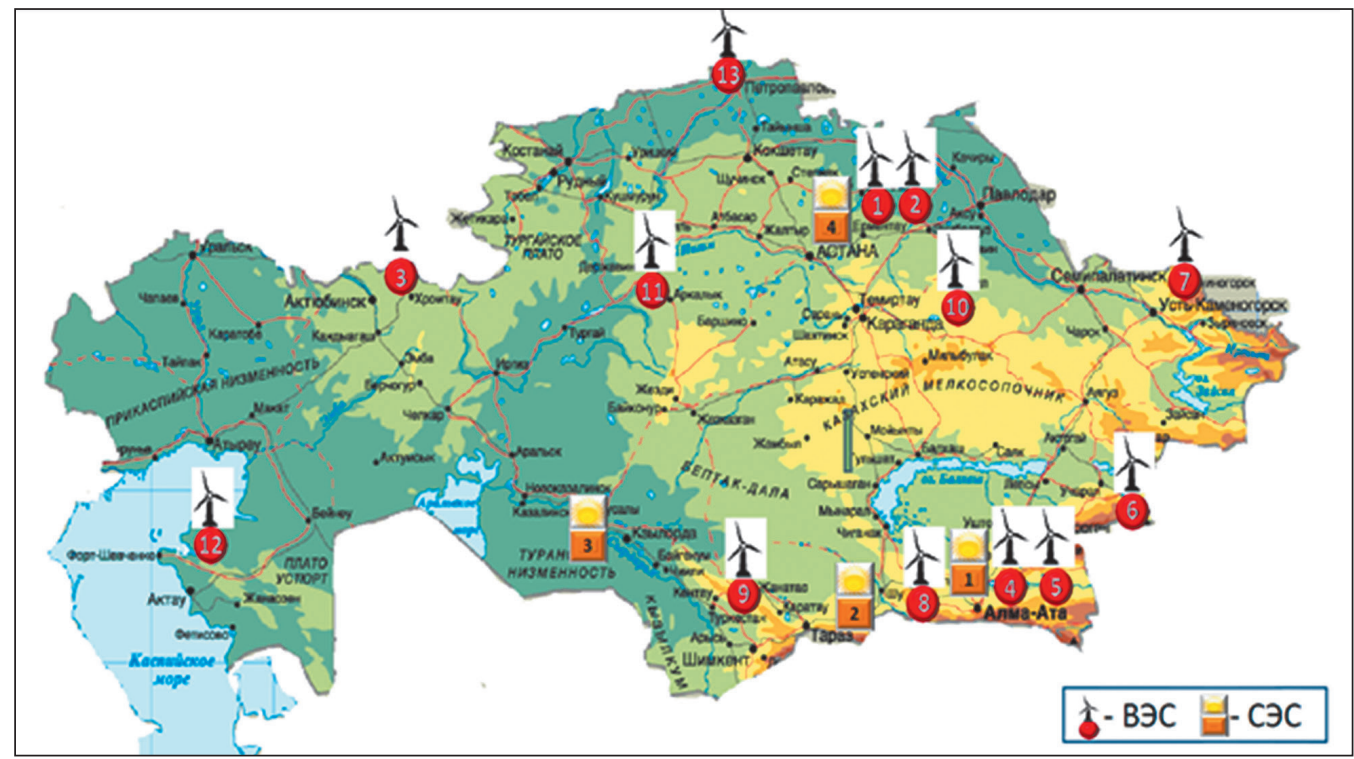

Рисунок 3 - Карта о возможности применения объектов ВИЭ (ВЭС и СЭС) в регионах Казахстана 


\section{АКТУАЛЬНО}

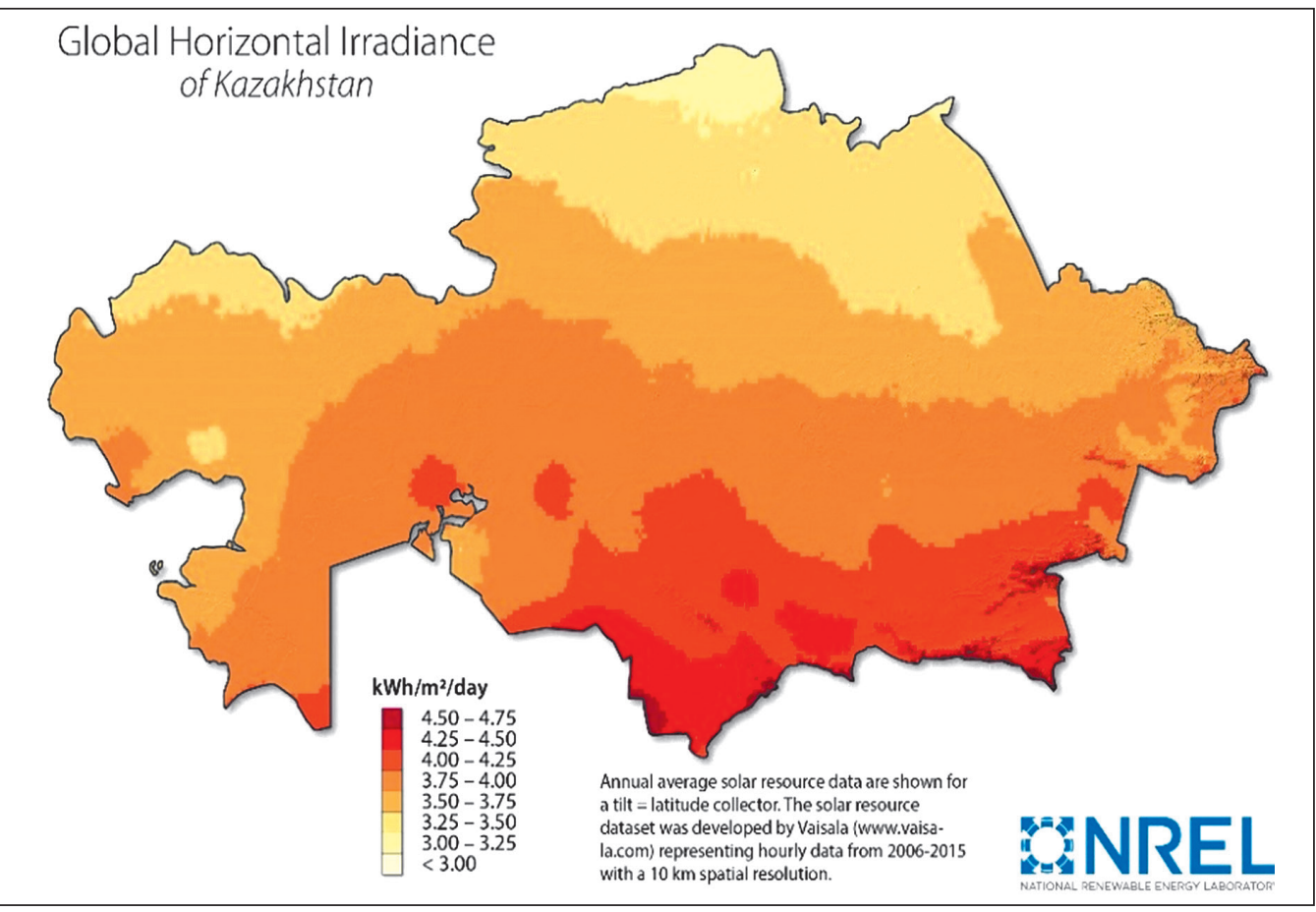

Рисунок 4 - Карта о годовой солнечной активности в регионах Казахстана

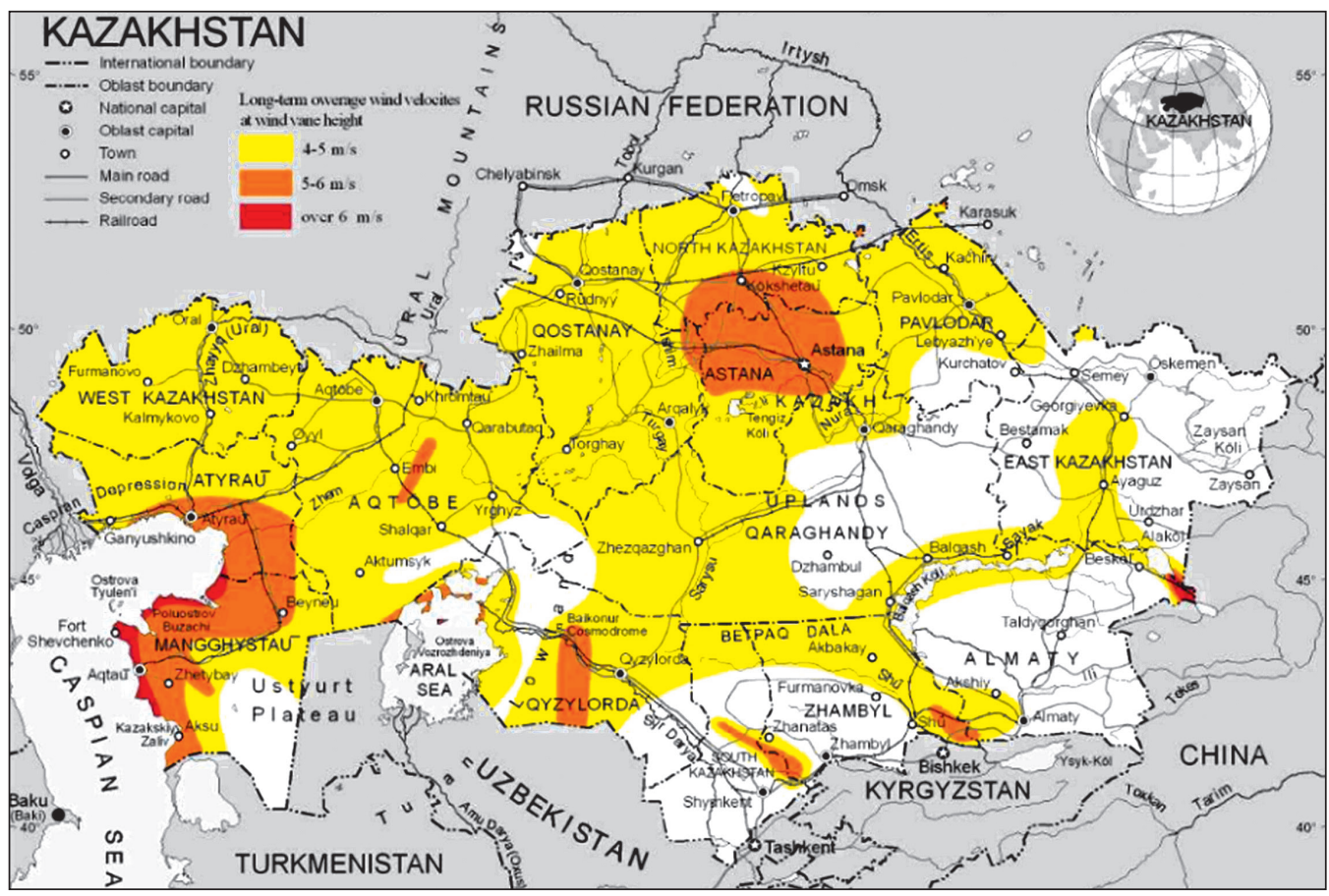

Рисунок 5 - Карта ветров (ветровой атлас) Казахстана с перспективными

для строительства ВЭС регионов 
После завершения в 2014 г. совместного проекта с ПРООН/ГЭФ «Казахстан инициатива развития рынка ветроэнергетики», в целях дальнейшего планомерного развития ветроэнергетики и ВИЭ в республике, Казахстанской электроэнергетической ассоциацией создан Комитет по ВИЭ, которому было поручено продолжение начатых ПРООН инициативы в секторе альтернативной энергетики. В результате проведения исследований ветроэнергетического потенциала Казахстана подготовлены проектные предложения по строительству ветроэлектростанций в Алматинской, Акмолинской, Мангистауской, Атырауской, Жамбылской и Карагандинской областях, а также в других регионах республики.

ВА Казахстана (рисунок 5) - это карта распределения скорости ветра на высоте 80 м над поверхностью Земли с размещением 9 км с указанием административных границ, городов, электрических сетей и подстанций, электростанции, железных и автомобильных дорог.

Таким образом, использованием этой карты можно предварительно определять перспективные районы для строительства ВЭС на территории республики. Это в свою очередь позволит создать основу для системного подхода по изучению ветровых ресурсов страны, провести их качественный анализ и подготовить практические рекомендации по выбору мест размещения ВЭС для получения электроэнергии.

В соответствии с рисунками 4 и 5, а также по данным, предоставленным партнером проекта ПРООН компанией Parsons Brinckendorf PB Power, можно сделать свод данных (таблица 1), позволяющих проанализировать ветропотенциал в разрезе регионов Казахстана [41].

Таблица 1 - Ветропотенциал перспективных для Казахстана регионов

\begin{tabular}{|c|c|c|c|c|c|c|}
\hline \multirow{2}{*}{$\begin{array}{c}\text { Категория по } \\
\text { диапазону } \\
\text { скоростей ветра } \\
\text { регионов РК }\end{array}$} & \multirow{2}{*}{$\begin{array}{c}\text { Площадь } \\
\text { региона, } \\
\text { км² }^{2}\end{array}$} & Низкая & Средняя & Высокая & Повышенная & Избыточная \\
\hline & & $<6 \mathrm{~m} / \mathrm{c}$ & $6-<7 \mathrm{~m} / \mathrm{C}$ & $7-<8 \mathrm{~m} / \mathrm{C}$ & $8-<9 \mathrm{~m} / \mathrm{C}$ & $>9 \mathrm{~m} / \mathrm{C}$ \\
\hline Акмолинская & 146,2 & 45,5 & 85,2 & 15,5 & 0 & 0 \\
\hline Актюбинская & 300,6 & 254,4 & 46,2 & 0 & 0 & 0 \\
\hline Атырауская & 118,6 & 58,1 & 60,5 & 0 & 0 & 0 \\
\hline $\begin{array}{c}\text { Западно- } \\
\text { Казахстанская }\end{array}$ & 151,3 & 61,4 & 89,9 & 0 & 0 & 0 \\
\hline Карагандинская & 428,0 & 343,1 & 84,6 & 0,3 & 0 & 0 \\
\hline Павлодарская & 124,8 & 37,7 & 87,1 & 0 & 0 & 0 \\
\hline Алматинская & 224,0 & 197,3 & 20,0 & 5,3 & 1,2 & 0,2 \\
\hline Жамбылская & 144,2 & 106,2 & 36,8 & 1,2 & 0 & 0 \\
\hline $\begin{array}{c}\text { Южно- } \\
\text { Казахстанская }\end{array}$ & 117,3 & 102,4 & 11,7 & 3,2 & 0 & 0 \\
\hline Костанайская & 196,0 & 81,5 & 114,5 & 0 & 0 & 0 \\
\hline $\begin{array}{c}\text { Северо- } \\
\text { Казахстанская }\end{array}$ & 98,04 & 0 & 82,8 & 15,24 & 0 & 0 \\
\hline $\begin{array}{c}\text { Восточно- } \\
\text { Казахстанская }\end{array}$ & 283,3 & 241,3 & 40,8 & 1,2 & 0 & 0 \\
\hline Мангистауская & 165,6 & 73,1 & 87,7 & 4,8 & 0 & 0 \\
\hline Кызылординская & 226,0 & 193,1 & 29,1 & 3,8 & 0 & 0 \\
\hline
\end{tabular}

Таблиияа создана с использованием данных, предоставленных компанией Parsons Brinckendorf PB Power 


\section{АКТУАЛЬНО}

Как видно из таблицы, не все регионы являются эффективными в применении энергии ветра. Из занимаемых площадей регионов Алматинская область является самым перспективным в отношении строительства ВЭС. В этой зоне есть места, где стабильная скорость ветра доходит до 9 м/с. Однако это не означает, что другие регионы, обозначенные в таблице 1, малоперспективны, если учесть наличие существующих в настоящее время новых технических средств, которые способны вырабатывать энергию даже при незначительных скоростях ветра 1,5 - 3 м/с [41].

В таблице 2 показаны потенциалы ветровой мощности регионов, в которых имеются зоны, где среднегодовая высокая скорость порыва ветров достигает до $8 \mathrm{~m} / \mathrm{c}$. В таблице 2 также показаны потенциалы мощности в переводе энергии ветра на электроэнергию, вырабатываемой посредством ВЭС.

Очевидно, что для эффективного внедрения в РК ВИЭ технологии на индустриальной основе необходимо учитывать опыт работы по данному направлению в соседних государствах и в дальнем зарубежье. При этом необходимо проанализировать научные и опытно-конструкторские разработки, которые позволяют проследить основные приоритеты применения ВИЭ, а также альтернативных технологий.

Таблица 2 - Энергетический потенциал предполагаемых ВЭС в регионах Казахстана

\begin{tabular}{|c|c|c|c|}
\hline $\begin{array}{c}\text { Категория по диапазону } \\
\text { скоростей ветра } \\
\text { регионов РК }\end{array}$ & $\begin{array}{c}\text { Высокая } \\
\text { скорость порыва } \\
\text { ветров }\end{array}$ & $\begin{array}{c}\text { Потенциал } \\
\text { ветровой } \\
\text { мощности, МВт }\end{array}$ & $\begin{array}{c}\text { Потенциал } \\
\text { электроэнергии, ГВт }\end{array}$ \\
\cline { 1 - 2 } Акмолинская & 15,5 & 108500 & 285100 \\
\hline Карагандинская & 0,3 & 2100 & 5500 \\
\hline Алматинская & 5,3 & 37100 & 97500 \\
\hline Жамбылская & 1,2 & 8400 & 22100 \\
\hline Южно-Казахстанская & 3,2 & 22400 & 58900 \\
\hline Северо-Казахстанская & 15,24 & 106400 & 279600 \\
\hline Восточно-Казахстанская & 1,2 & 8400 & 22100 \\
\hline Мангистауская & 4,8 & 33600 & 88300 \\
\hline Кызылординская & 3,8 & 26600 & 69900 \\
\hline
\end{tabular}

Таблица создана с использованием данных, предоставленных компанией Parsons Brinckendorf PB Power

В работе [44] проанализировано существующее по состоянию на 2012 г. положение с энергетикой, энергосбережением и ВИЭ в Казахстане, с подробной оценкой их потенциала в стране в разрезе гидроэнергетики, энергии ветра, солнечной энергия и энергии биотоплив. Изучена государственная политика РК в области энергосбережения и ВИЭ, государственная поддержка их использования. Проанализирована текущая ситуация использования энергоресурсов в экономике Казахстана, в частности оценка использования энергоресурсов и энергоэффективности в экономике страны, использования ВИЭ и их составных элементов. Проведена оценка наиболее подходящих технологий для приоритетных областей потребления энергии, определены барьеры на пути инвестиций в передовые энергосберегающие технологии и технологии ВИЭ. 
В работе [45] рассмотрен опыт развитых стран по внедрению экономических механизмов снижения вредных выбросов и использования возобновляемых источников энергии. Исследована возможность использования возобновляемых ресурсов в Казахстане. Обоснована целесообразность применения передового мирового опыта по административному управлению охраной окружающей среды в сочетании с экономическими методами, широко применяемыми странами с развитой рыночной экономикой.

В работе [46] для получения эффективной энергии от ветра решается задача сохранения устойчивости напряжения и сила тока. Для этого энергию ветра для начала преобразовывают в молекулярную энергию сжатых газов, затем из этой энергии получают устойчивую и простую в использовании электроэнергию. Здесь сохраняется тот принцип, где самым эффективным способом получения электроэнергии является тепловая электростанция, т.к. в ней движущими силами являются высокотемпературные пары воды, которые также представляют собой молекулярную энергию сжатых газов. Другими словами, здесь наблюдается эффективность превращения энергии ветра в молекулярную энергию сжатых газов. Для осуществления описанных выше факторов авторами предлагается создание конструкции гибридной ветростанции, т.е. как это заметно, процесс гибридизации в Казахстане также активно начал продвигаться вперед.

В работе [47] рассматриваются вопросы построения оптимальных систем автономного энергоснабжения агропромышленного комплекса (АПК) с использованием возобновляемых источников энергии (ВИЭ), где актуальным является проблема выявления закономерностей распределения зон оптимального использования различных ВИЭ и их сочетания, путем сравнения их эксплуатационных и экономических показателей. При этом эффективным инструментом определения зон оптимального применения различных видов ВИЭ, является системный подход, который позволяет провести комплексный анализ объекта и строго систематизировать исследования, а также осуществить синтез, т.е. найти систему, оптимальную для заданных условий.

На современном этапе развития Казахстана одним из операторов проектов, реализуемых в области ВИЭ, а также нетрадиционных и альтернативных технологий производства энергии является Объединение юридических лиц «Казахстанская Ассоциация организаций нефтегазового и энергетического комплекса «Kazenergy» (далее «Kazenergy»). Данная организация была создана 2 ноября 2005 г. с целью поддержки развития предпринимательства в нефтегазовой сфере. В настоящее время сфера деятельности данной компании значительно расширился, и она стала заниматься вопросами нефтегазовых технологий, а также экологическими вопросами топливно-энергетического комплекса (ТЭО), в том числе и ВИЭ. Об этом свидетельствуют результаты исследований, опубликованные в сборниках научно-технического совета «Kazenergy» [48-50]. Анализ работ свидетельствует об активизации разработок по инновационным проектам ТОО «Samruk-Green Energy» в области солнечной энергетики, мини-ГЭС и роботизации генерирования электроэнергии от ВИЭ.

В развитии «зеленой экономики» («зеленая энергетика») Казахстана, несомненно, ведущую роль играет Международный центр зеленых технологий и инвестиционных проектов (Центр), созданный Постановлением Правительства РК от 


\section{АКТУАЛЬНО}

27 апреля 2018 г. как практическое воплощение инициативы Первого Президента Республики Казахстан Нурсултана Назарбаева по развитию инфраструктуры и наследия выставки «Астана ЭКСПО-2017», которую он выдвинул на 70-й юбилейной сессии Генеральной Ассамблеи ООН.

За короткое время с момента основания Центр стал главным оператором Глобальной инновационной программы чистых технологий UNIDO CleanTech, продвигающем «зеленые» технологии, а также Национальным координатором Платформы ЕС-Центральная Азия в сфере охраны окружающей среды и водных ресурсов проекта WECOOP. Центр принял активное участие в разработке Экологического кодекса РК, где начиная с 1 января 2025 г. предусмотрен переход промышленных предприятий на комплексные экологические разрешения с применением принципов наилучших доступных технологий (НДТ).

Одним из важных моментов проекта НДТ является предусмотренная программой разработка различных межотраслевых справочников, которые практически охватывают все секторы ТЭО. Эти справочники нацелены на обеспечение экологической безопасности деятельности производственных предприятий ТЭО, и в их разработке задействованы ученые профильных специализированных вузов и научных организаций Казахстана. В разработке справочника по наилучшим доступным техникам «Переработка нефти и газа» планируется участие Атырауского университета нефти и газа им. С. Утебаева.

Подытоживая обзор, можно отметить, что по состоянию на сегодняшний день в республике проделана достаточно большая работа по внедрению альтернативных и возобновляемых источников энергии (АВИЭ). Задачей последующих этапов является разработка методов и способов, направленных на реализацию АВИЭ на индустриальной основе, где применение экономической методологии и принципов должно принести хорошие результаты.

Предлагаем в качестве одного из эффективных методов управления проектами применить метод сравнительного ранжирования мотивации (причин), который должен способствовать (или не способствовать) наступлению событий, в данном случае конечной целью будет внедрение АВИЭ в электроэнергетическом комплексе в качестве дополнительных источников мощностей (рисунок б). Данная блок-схема поможет нам сориентироваться для правильного выбора последовательных взаимосвязанных действий и шагов, а также необходимые технические и организационные условия, без которых невозможно будет реализовать применение АВИЭ на индустриальной основе.

\section{Выводы}

1. Сделанный обзор состояния проблемы, а также анализ результатов существующих технических достижений и исследований в области ВИЭ, альтернативных и нетрадиционных технологий позволил проследить перспективные направления их дальнейшего совершенствования для внедрения в производство на индустриальной основе.

2. Предложенные блок-схемы последовательности анализа существующих научных разработок в области АВИЭ, а также предложенные новые подходы в 


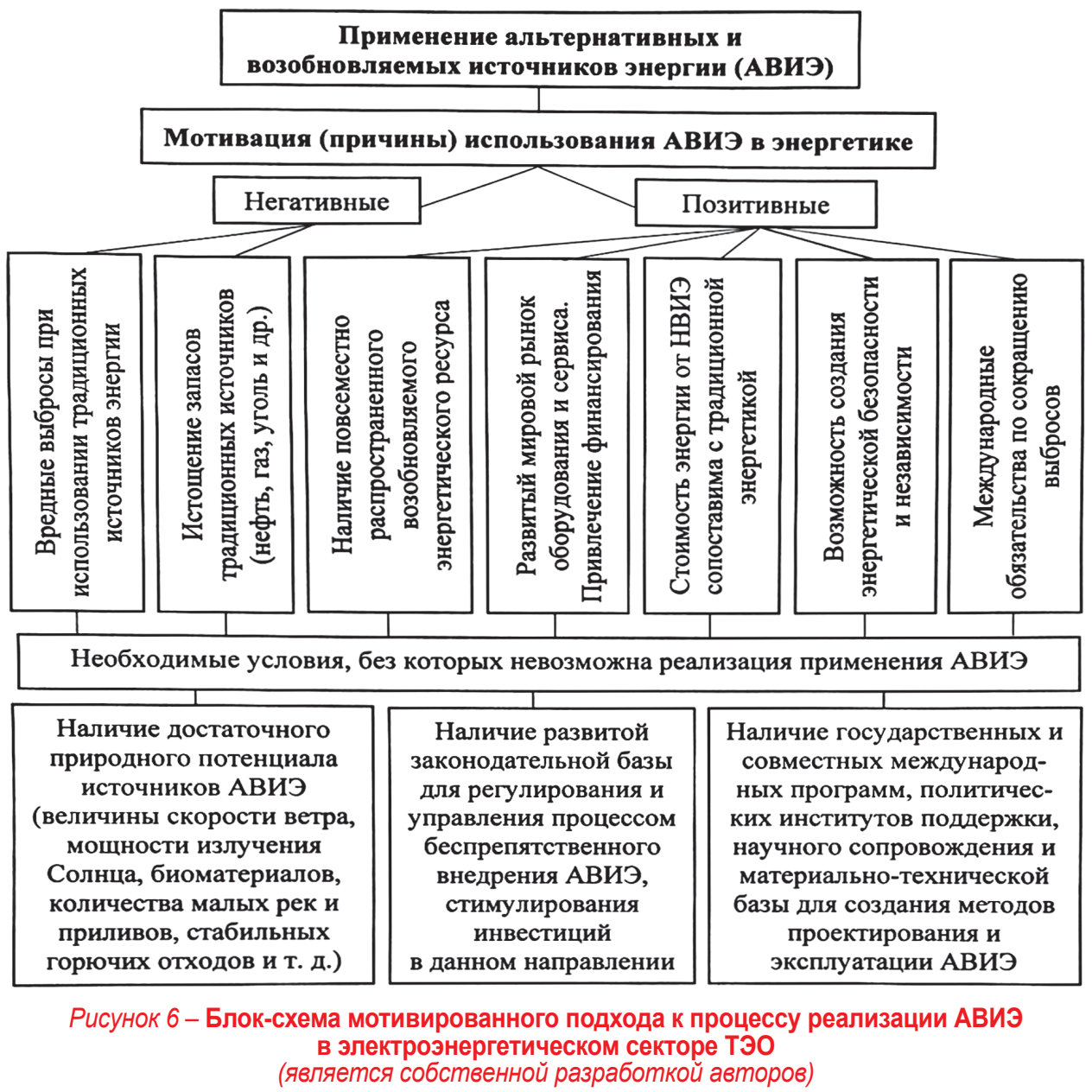

определении мотивации использования в энергетическом секторе Казахстана альтернативных и возобновляемых источников энергии позволяют методически правильно определить необходимые условия для их реализации, и таким образом систематизировать процесс развития в Казахстане «зеленой экономики».

\section{ЛИТЕРАТУРА}

1 Fernando-Evaristo Callejas-Albiñana, Miguel-Ángel Tarancón and Isabel MartínezRodríguez. Econometric Studies on the Development of Renewable Energy Sources to Support the European Union 2020-2030 Climate and Energy Framework: A Critical Appraisal // Sustainability. - 2020. -12 (12). - P. 4828 / Seminar on Sustainable Economy, Faculty of Law and Social Sciences, University of Castilla-La Mancha, Ronda de Toledo s/n., 13071 Ciudad Real, Spain https://doi.org/10.3390/su12124828, https://www.mdpi. com/2071-1050/12/12/4828/htm

2 Luis Mundaca, Xianli Zhu ang Markus Hackenfort. Behavioural insights for sustainable energy use: Theories, evidence and policy implications // J. Energy Policy. - 2021. - No.11. https://www.sciencedirect.com/journal/energy-policy/special-issue/10DZN72ZKMB 
3 Batara Surya, Agus Salim, Haeruddin Saleh and others. Economic Growth Model and Renewable Energy Utilization: Perspective of Natural Resources Management and Sustainable Development of The Gowa Regency Region South Sulawesi, Indonesia // In. J. of Energy Economics and Policy (IJEEP). - 2021. - Vol. 11. - No 6. - Pp. 68-90 https://www.econjournals.com/index.php/ijeep/article/view/11676

4 Султанов Б.К. Послание Президента Республики Казахстан - Лидера нации Н.А. Назарбаева народу Казахстана «Стратегия «Казахстан-2050»: новый политический курс состоявшегося государства». - Материалы мероприятий, посвященных обсуждению Послания Главы государства / Отв. ред. Б.К. Султанов. - Алматы: Казахстанский институт стратегических исследований при Президенте Республики Казахстан, 2013. - 228 c. [Sultanov B.K. Message of the President of the Republic of Kazakhstan - Leader of the Nation N.A. Nazarbayev to the people of Kazakhstan "Strategy "Kazakhstan-2050": a new political course of the established state". - Materials of events dedicated to the discussion of the Address of the Head of State / Ed. by B.K. Sultanov. - Almaty: Kazakhstan Institute for Strategic Studies under the President of the Republic of Kazakhstan, 2013. - 228 p.]

5 Постановление Правительства Республики Казахстан № 479 от 29 июля 2020 г. «Об утверждении Плана мероприятий по реализации Концепции по перехода Республики Казахстан к «зеленой экономике» на 2021-2030 гг.». URL: https://adilet.zan.kz/rus/ docs/P2000000479 (дата обращения 20.06.2021 г.) [Resolution of the Government of the Republic of Kazakhstan No. 479 dated July 29, 2020 "On approval of the Action Plan for the implementation of the Concept for the Transition of the Republic of Kazakhstan to a "green economy" for 2021-2030". URL: https://adilet.zan.kz/rus/docs/P2000000479 (accessed 20.06.2021)]

6 Концепция по переходу Республики Казахстан к «зеленой экономике». 2013. 52 с. https://greenkaz.org/images/for_news/pdf/npa/koncepciya-po-perehodu.pdf [The concept of the transition of the Republic of Kazakhstan to a "green economy". 2013. 52 p. https:// greenkaz.org/images/for_news/pdf/npa/koncepciya-po-perehodu.pdf]

7 В столице обсудили вопросы реализации Концепции по переходу Казахстана к «зеленой» экономике. Официальный информационный ресурс Комитета лесного хозяйства и животного мира Министерства экологии, геологии и природных ресурсов РК. Материалы от 26.05.2021г. https://www.gov.kz/memleket/entities/forest/press/news/ details/207561?lang=ru (дата обращения 20.06.2021г.) [Issues of implementation of the Concept of Kazakhstan's transition to a "green economy" were discussed in the capital. The official information resource of the Forestry and Wildlife Committee of the Ministry of Ecology, Geology and Natural Resources of the Republic of Kazakhstan. Materials from 26.05.2021 https://www.gov.kz/memleket/entities/forest/press/news/details/207561 ?lang=ru (accessed 20.06.2021)]

8 Повестка дня на XXI век. - Материалы конференция ООН по окружающей среде и развитию. - Рио-де-Жанейро: 1992. - 237 с. [The agenda for the XXI century. Proceedings of the UN Conference on Environment and Development. - Rio de Janeiro: $1992-237$ p.]

9 Храмков А. «Зеленая экономика» для Казахстана / газета «Литер». - 2012. - 26 декабря. [Khramkov A. "Green economy" for Kazakhstan / newspaper "Liter". - 2012. December 26.]

10 Соспанова А. О развитии ВИЭ. Официальный информационный ресурс Премьер-Министра РК: «Переход РК к «зеленой экономике», подготовка кадров и привлечение инвесторов». Материалы интервью от 30.09.2019г. https://www.primeminister.kz/ru/news/ interviews/perehod-rk-k-zelenoy-ekonomike-podgotovka-kadrov-i-privlechenie-investorova-sospanova-o-razvitii-vie [Sospanova A. On the development of renewable energy. 
The official information resource of the Prime Minister of the Republic of Kazakhstan: "Transition of the Republic of Kazakhstan to a "green economy", training and attracting investors." Interview materials from 30.09.2019 https://www.primeminister.kz/ru/news/ interviews/perehod-rk-k-zelenoy-ekonomike-podgotovka-kadrov-i-privlechenie-investorova-sospanova-o-razvitii-vie]

11 Друзь Н., Борисова Н., Асанкулова А., Раджабов И., Захидов Р. Таджиев У. Положение дел по использованию возобновляемых источников энергии в Центральной Азии. Перспективы их использования и потребности в подготовке кадров. Обзор. Алматы: Кластерное бюро ЮНЕСКО по Казахстану, Кыргызстану, Таджикистану и Узбекистану, 2010. - 144 c. [Druz N., Borisova N., Asankulova A., Rajabov I., Zahidov $R$. Tajiev U. The state of affairs on the use of renewable energy sources in Central Asia. Prospects for their use and training needs. Review. Almaty: UNESCO Cluster Office for Kazakhstan, Kyrgyzstan, Tajikistan and Uzbekistan, 2010. - 144 p.]

12 Божко Л.Л. Особенности индустриально-инновационного развития Республики Казахстан: монография / Л.Л. Божко. - Рудный: Руднен. индустриальный ин-т, 2017. - 105 c. [Bozhko L.L. Features of industrial and innovative development of the Republic of Kazakhstan: monograph / L.L. Bozhko. - Rudny: Rudnen Publishing House. industrial institute, 2017. - 105 р.]

13 Сборник аналитических справок по результатам анализа эффективности законодательства (1996-2018 гг. и 4-квартал 2019 года). - Нур-Султан: Центр правового мониторинга Института законодательства и правовой информации Республики Казахстан, 2020. - 537 с. [Collection of analytical reports on the results of the analysis of the effectiveness of legislation (1996-2018 and the 4th quarter of 2019). - Nur-Sultan: Center for Legal Monitoring of the Institute of Legislation and Legal Information of the Republic of Kazakhstan, 2020. - 537 p.]

14 Hansen J. T., Mahak M., Tzanakis I. Numerical modelling and optimization of vertical axis wind turbine pairs: A scale up approach // Renewable Energy. - 2021. - Vol. 171. - Pp. 1371-1381 journal homepage: www.elsevier.com/locate/renene

15 Möllerströma E., Gipeb P., Beurskensc J., Ottermoa F. A historical review of vertical axis wind turbines rated $100 \mathrm{~kW}$ and above // Renewable and Sustainable Energy Reviews. - 2019. - Vol. 105. - Pp. 1-13. journal homepage: www.elsevier.com/locate/rser

16 Zong H., Porte-Agel F. Experimental investigation and analytical modelling of active yaw control for wind farm power optimization // Renewable Energy. - 2021. - Vol. 170. - Pp. 1228-1244. journal homepage: www.elsevier.com/locate/renene

17 Boehringer Chr., Landis F., Tovar Reanos M. Ang. Economic Impacts of Renewable Energy Promotion in Germany // The Energy Journal. - 2021. - Vol. 38. - Pp. 189-209. https://doi.org/10.5547/01956574.38.SI1.cboh

18 Jurasz J., Canalesc F.A., Kiesd A., Guezgouz M., Beluco A. A review on the complementarity of renewable energy sources: Concept, metrics, application and future research directions // Solar Energy. - 2020. - Vol. 195. - Pp. 703-724. journal homepage: www.elsevier.com/locate/solene

19 Bazdara E., Shirzadi N. Economic Analysis and Simulation of Solar PV, Wind Turbine Hybrid Energy System Using HOMER pro // Journal of Solar Energy Research. - 2017. - Vol. 23. - Pp. 53-58

20 Mamani R., Hendrick P. Weather research \& forecasting model and MERRA-2 data for wind energy evaluation at different altitudes in Bolivia // Wind Engineering. - 2021. - No 5. - Pp. 1565-1573 https://doi.org/10.1177/0309524X211019701

21 Matthew J. Burkea, $*$, Jennie C. Stephensb Political power and renewable energy futures: A critical review // Energy Research \& Social Science. - 2018. - Vol. 35. - Pp. 78-93 
22 Naserpour Somayeh, Zolfaghari Hasan, Firouzabadi Parviz Zeaiean. Estimation of Solar Radiation Energy in the Paraw Mountain of Kermanshah Province as a Rugged Topography // Journal of Renewable Energy and Environment. - 2021. - Vol. 8. - Is. 2. - Pp. 1-12. http://dx.doi.org/10.30501/jree.2020.239778.1130

23 Uraltas Yunus, Yumurtaci Zehra. Study on On-Shore and Off-Shore Wind Power Plant (Wpp) Micro-Siting in Adalar District (Princes' Islands) and Analysis of Energy Generation // International Journal of Renewable Energy Research. - 2021. - Vol. 11. - No. 2. - Pp. 709-720.

24 Мудрецов А.Ф., Прудникова А.А. Экологические проблемы устойчивого развития в трансформирующейся экономике // Международный научн.-иссл. электрон. журнал Ин-та проблем рынка РАН «Проблемы рыночной экономики». - 2020. - № 4. - С. 113120 [Mudretsov A.F., Prudnikova A.A. Environmental problems of sustainable development in a transforming economy // International scientific-research electron. Journal of the Institute of Market Problems of the Russian Academy of Sciences "Problems of Market Economy". - 2020. - No. 4. - Pp. 113-120]

25 Перминов Э.М. К вопросу о ветроэнергетике: история, состояние, перспективы // Вестник МЭИ. - 2020. - № 5. - C. 11-26. DOI: 10.24160/1993-6982-2020-5-11-26. [Perminov E.M. On the issue of wind power: history, state, prospects // Bulletin of the MEI. - 2020. - No. 5. - Pp. 11-26. DOI: 10.24160/1993-6982-2020-5-11-26.]

26 Манигомба Ж.А., Чичирова Н.Д., Груздев В.Б. Перспективы использования продуктов пиролиза в дизель-генераторах промышленной группы «Regideso» в Республике Бурунди // Проблемы энергетики. - 2018. - Том 20. - № 1 -2. - С. 33-40. [Manigomba Zh.A., Chichirova N.D., Gruzdev V.B. Prospects for the use of pyrolysis products in diesel generators of the industrial group "Regideso" in the Republic of Burundi // Problems of Energy. - 2018. - Volume 20. - No. 1-2. - Pp. 33-40.]

27 Попель С. Возобновляемые источники энергии: роль и место в современной и перспективной энергетике // Российский химический журнал (Журнал Российского химического общества им. Д. И. Менделеева). - 2008. - T. LII. - №6. - C. 95-106 [Popel S. Renewable energy sources: the role and place in modern and promising energy // Russian Chemical Journal (Journal of the Russian Chemical Society named after D. I. Mendeleev). - 2008. - Vol. LII. - No. 6. - Pp. 95-106]

28 Томаров Г.В. Геотермальные энерготехнологии России // Вестник МЭИ. - 2020. - № 4. - C. 29 - 41. DOI: 10.24160/1993ᄀ6982-2020-4-29-41. [Tomarov G.V. Geothermal energy technologies of Russia // Vestnik MEI. - 2020. - No. 4. - Pp. 29 - 41. DOI: 10.24160/19936982-2020-4-29-41.]

29 Сигитов О.Ю., Чемборисова Н.Ш. Расстановка ветровых электростанций в электроэнергетической системе // Вестник МЭИ. - 2021. - № 1. - C. 21-32. DOI: https://doi. org/10.24160/1993-6982-2021-1-21-32 [Sigitov O. Yu., Chemborisova N. Sh. Arrangement of wind power plants in the electric power system // Bulletin of the MEI. 2021. No. 1. pp. 21-32. DOI: https://doi.org/10.24160/1993-6982-2021-1-21-32]

30 Ачитаев А.А., Жидков А.А., Кашурников М.В. Оценка эффрективности использования возобновляемых источников энергии с учётом необходимости выработки тепловой энергии // Известия НТЦ Единой энергетической системы. - 2021. - № 1 (80). - С. 132-142 [Achitaev A.A., Zhidkov A.A., Kashurnikov M.V. Evaluation of the efficiency of using renewable energy sources taking into account the need to generate thermal energy // Izvestiya STC Unified Energy System. - 2021. - No. 1 (80). - P. 132-142]

31 Ахмед 3.А., Павлюченко Д.А., Лесс В.М. Математическая модель оптимального размещения гибридной электростанции с комбинированным циклом // Известия высших учебных заведений «Проблемы энергетики». - 2021. - №23 (1). - C. 18-32. https:// doi.org/10.30724/1998-9903-2021-23-1-18-32 [Ahmed Z.A., Pavlyuchenko D.A., Less 
V.M. Mathematical model of optimal placement of a hybrid power plant with a combined cycle // Izvestia of higher educational institutions "Problems of energy". - 2021. - No.23 (1). - P. 18-32. https://doi.org/10.30724/1998-9903-2021-23-1-18-32]

32 Мирошниченко А.А., Соломин Е.В., Гордиевский Е.М., Кулганатов А.З., Станчаускас В.И. Анализ стратегий управления гибридным энергокомплексом на базе возобновляемых источников энергии // Вестник МЭИ. - 2020. - № 5. - C. 67-78. DOI: 10.24160/1993-6982-2020-5-67-78. [Miroshnichenko A.A., Solomin E.V., Gordievsky E.M., Kulganatov A.Z., Stanchauskas V.I. Analysis of strategies for managing a hybrid energy complex based on renewable energy sources // Vestnik MEI. - 2020. - No. 5. Pp. 67-78. DOI: 10.24160/1993-6982-2020-5-67-78]

33 Тягунов М.Г., Шевердиев Р.П. Влияние режимов работы гибридных энергетических комплексов на основе возобновляемых источников энергии на определение типа аккумуляторов энергии // Вестник МЭИ. - 2020. - №4. - C. 62-70. DOI: 10.24160/1993 6982-2020-4-62-70. [Tyagunov M.G., Sheverdyev R.P. The influence of operating modes of hybrid energy complexes based on renewable energy sources on the determination of the type of energy accumulators // Vestnik MEI. - 2020. - No. 4. - Pp. 62-70. DOI: 10.24160/19936982-2020-4-62-70.]

34 Филимонова А.А., Чичиров А.А., Чичирова Н.Д., Филимонов А.Г., Печенкин А.В. Перспективы развития водородной энергетики в Татарстане // Известия высших учебных заведений «Проблемы энергетики». - 2020. - №22 (6). - С. 79-91. https://doi. org/10.30724/1998-9903-2020-22-6-79-91 [Filimonova A.A., Chichirov A.A., Chichirova N.D., Filimonov A.G., Pechenkin A.V. Prospects for the development of hydrogen energy in Tatarstan // News of higher educational institutions "Problems of energy". - 2020. No.22 (6). - P. 79-91. https://doi.org/10.30724/1998-9903-2020-22-6-79-91]

35 Плетнев М.А., Копысов А.Н. Социально-экономические проблемы развития водородной энергетики // Известия высших учебных заведений. «Проблемы энергетики». - 2021. - №23 (2). - C. 36-45. https://doi.org/10.30724/1998-9903-2021-23-2-36-45 [Pletnev M.A., Kopysov A.N. Socio-economic problems of hydrogen energy development // News of higher educational institutions. "Energy problems". - 2021. - No.23 (2). - Pp. 36-45. https://doi.org/10.30724/1998-9903-2021-23-2-36-45]

36 Мехтиев А.Д., Алькина А.Д., Югай В.В., Есенжолов У.С., Калиаскаров Н.Б. Сравнительный анализ и перспективы использования многотопливных микро тепловых электростанций на основе двигателя стирлинга для сельских районов // Известия высших учебных заведений. «Проблемы энергетики». - 2020. - №22(5). - C. 3-17. https://doi.org/10.30724/1998-9903-2020-22-5-3-17 [Mekhtiev A.D., Olkina A.D., Yugai V.V., Yesenzholov U.S., Galiaskarov N.B. Comparative analysis and prospects of using multi-fuel micro thermal power plants based on Stirling engine for rural areas // News of higher educational institutions. "Energy problems". - 2020. - No.22(5). - P. 3-17. https:// doi.org/10.30724/1998-9903-2020-22-5-3-17]

37 Горбунова М.Л., Куасси Яо Донатьен. Возобновляемые источники энергии в системе децентрализованного энергоснабжения ряда округов Кот д'Ивуар // Вестник МЭИ. - 2021. - № 1. - С. 56-61. DOI: https://doi.org/10.24160/1993-6982-2021-1-56-61 [Gorbunova M.L., Kouassi Yao Donatien. Renewable energy sources in the system of decentralized energy supply in a number of districts of Ivory Coast // Bulletin of the MEI. - 2021. - No. 1. - Pp. 56-61. DAY: https://doi.org/10.24160/1993-6982-2021-1-56-61]

38 Колганов А.В., Гусейнов Ч.С., Портнягин Н.Н. Подводный энергоагрегат как альтернативный источник энергии // Защита окружающей среды в нефтегазовом комплексе. - 2021. - №3. - Ч. 1. - C. 50-53. DOI: 10.33285/2411-7013-2021-3(300)-50-53 [Kolganov A.V., Huseynov Ch.S., Portnyagin N.N. Underwater power unit - as an alternative energy source // Environmental protection in the oil and gas complex. - 2021. - No. 3. - Part 1. - P. 50-53. DOI: 10.33285/2411-7013-2021-3(300)-50-53] 
39 Ахметов С.М., Билашев Б.А., Ихсанов К.А., Харитонов П.Т., Икласова Ж.У. Перспективы применения в нефтяных и газовых промыслах Казахстана возобновляемых и альтернативных источников энергии // Защита окружающей среды в нефтегазовом комплексе. - 2021. - №7. - С. 29-32 [Akhmetov S.M., Bilashev B.A., Ihsanov K.A., Kharitonov P.T., Iklasova Zh.U. Prospects of application of renewable and alternative energy sources in oil and gas fields of Kazakhstan // Environmental protection in the oil and gas complex. - 2021. - №7. - Pp. 29-32]

40 Ван Ден Эккер Я., Ни В. Казахстан - инициатива развития рынка ветроэнергетики. Отчет по среднесрочной оценке. ПРООН/ГЭФ, 2007. - 59 с. [Van Den Ecker Ya., Ni V. Kazakhstan - Wind Energy Market Development Initiative. Mid-term evaluation report. UNDP/GEF, 2007. - 59 p.]

41 Раков М. Ветровой атлас Казахстана. Проект ПРООН: Казахстан - инициатива развития рынка ветроэнергии. - Астана, 2011. - 32 с. [Rakov M. Wind Atlas of Kazakhstan. The UNDP project: Kazakhstan is an initiative for the development of the wind energy market. - Astana, 2011. 32 p.]

42 Национальный доклад по переходу Республики Казахстан к «зеленой экономике» за 2017 - 2018 годы. - Нур-Султан, 2019. URL: https://igtipc.org/images/docs/2020/ proekt_doklada01.pdf [National report on the transition of the Republic of Kazakhstan to a "green economy" for 2017-2018. - - Nursultan, 2019. URL: https://igtipc.org/images/ docs/2020/proekt_doklada01.pdf]

43 За год в Казахстане запустили 21 крупный объект ВИЭ. В целом в стране 90 действующих объектов возобновляемых источников энергии. URL: https://kapital.kz/ economic/83914/za-god-v-kazakhstane-zapustili-21-krupnyy-ob-yekt-vie.html [During the year, 21 large renewable energy facilities were launched in Kazakhstan. In general, there are 90 existing renewable energy facilities in the country. URL: https://kapital.kz/ economic/83914/za-god-v-kazakhstane-zapustili-21-krupnyy-ob-yekt-vie.html]

44 Трофимов Г.Г. Анализ развития и распространения передовых технологий в области энергоэффективности и возобновляемой энергетики в Казахстане. Проект Европейской Экономической Комиссии ООН «Анализ развития и распространения передовых технологий в области энергоэффективности и возобновляемой энергетики в рамках проекта «Глобальная энергоэффективность 21» для стран Центральной Азии». - Алматы, 2012. - 50 c. [Trofimov G.G. Analysis of the development and dissemination of advanced technologies in the field of energy efficiency and renewable energy in Kazakhstan. The UN Economic Commission for Europe project "Analysis of the development and dissemination of advanced technologies in the field of energy efficiency and renewable energy within the framework of the Global Energy Efficiency 21 Project for Central Asian countries". - Almaty, 2012. - 50 p.]

45 Сейтхамзина Г.Ж., Каирова Ш.Г. Опыт развитых стран по внедрению экономического механизма снижения вредных выбросов и возобновляемых источников энергии // Вестник КазНУ им. Аль-Фараби. Серия экологическая. - 2013. - №2/1 (38). - С. 138144. [Seithamzina G.Zh., Kairova Sh.G. The experience of developed countries on the introduction of an economic mechanism for reducing harmful emissions and renewable energy sources // Bulletin of Al-Farabi Kazakh National University. The series is ecological. - 2013. - No.2/1 (38). - Pp. 138-144.]

46 Жилкашинова А.М. Перспективы внедрения гибридных ветроэлектростанций в Казахстане // Научный журнал Национального ядерного центра РК «Человек. Энергия. Атом». - 2015. - №1 (23). - C. 62-65 [Zhilkashinova A.M. Prospects for the introduction of hybrid wind farms in Kazakhstan // Scientific Journal of the National Nuclear Center of the Republic of Kazakhstan "Man. Energy. Atom". - 2015. - No. 1 (23). - Pp. 62-65] 
47 Кешуов С.А., Байсенова Г.С., Молдыбаева Н.И. Синтез структуры систем автономного энергоснабжения на основе возобновляемых источников энергии // Вестник Алматинского университета энергетики и связи. - 2020. - No4 (51). - C. 27 - 41 [Keshuov S.A., Beisenova G.S., Maldybayeva N.I. Synthesis of the structure of autonomous power supply systems based on renewable energy sources // Bulletin of the Almaty University of Energy and Communications. - 2020. - No4 (51). - Pp. 27 - 41]

48 Моминбаев Ж.Б. Солнечная энергетика: инновационные проекты TOО «SamrukGreen Energy». Сб. докл. НТС «Kazenergy». Том 1 / Под. ред. д.т.н., профрессора У.С. Карабалина. - Ассоциация «Kazenergy». - Нур-Султан, 2019. - С. 349-361. [Mominbayev Zh.B. Solar energy: innovative projects of "Samruk-Green Energy" LLP. Sat. dokl. NTS "Kazenergy". Volume 1 / Edited by Doctor of Technical Sciences, Professor U.S. Karabalin. - Kazenergy Association. - Nur-Sultan, 2019. - Pp. 349-361.]

49 Мухаметкалиев Б.К. Мини-ГЭС в контейнерном (бизнес-модель). Сб. докл. НТС «Kazenergy». Том 1 / Под. ред. д.т.н., профессора У.С. Карабалина. - Ассоциация «Kazenergy». - Нур-Султан, 2019. - С. 367-371. [Mukhametkaliev B.K. Mini-hydroelectric power station in container (business model). Collection of documents. NTS "Kazenergy". Volume 1 / Edited by Doctor of Technical Sciences, Professor U.S. Karabalin. - Kazenergy Association. - Nur-Sultan, 2019. - Рp. 367-371.]

50 Шоланов К.С. Роботизация генерирования электроэнергии от возобновляемых источников энергии. Сб. докл. НТС «Kazenergy». Том 1 / Под. ред. д.т.н., профресcора У.С. Карабалина. - Ассоциация «Kazenergy». - Нур-Султан, 2019. - С. 372-376. [Sholanov K.S. Robotization of electricity generation from renewable energy sources. Sat. dokl. NTS "Kazenergy". Volume 1 / Edited by Doctor of Technical Sciences, Professor U.S. Karabalin. - Kazenergy Association. - Nur-Sultan, 2019. - Pp. 372-376.] 